\title{
Analysis of customer relationship management in hospitals and present an efficient model for CRM implementation in hospitals
}

\author{
Ehsan ZAMANI ${ }^{1}$, Mohammad Jafar TAROKH ${ }^{2}$ \\ ${ }^{1}$ Faculty of Computer and Information Technology Engineering, Qazvin Branch, Islamic Azad \\ University, Qazvin, Iran. Ehsan.zamani.70@gmail.com \\ ${ }^{2}$ Faculty member of Department of Industrial Engineering, Khajeh Nasiroddin Toosi University, \\ Tehran , Iran. mjtarokh@kntu.ac.ir
}

\begin{abstract}
:
Today, as a business unit, health care organizations are more requiring high standards of customer relationship management from other industries. This study formed by organizational perspective to identify factors affecting customer satisfaction in medical centers .The study sample in this research is all the people who are somehow connected with hospitals for treatment and the sample size is 303 patients. In this study our aim is to introduce a model of customer relationship management which consists of seven components and the relationship between them. The model is the result of more than 40 models introduced and validated in the field of customer relationship management that presented since 1996 to the present. In the analysis done on data, we proved the new introduced model.
\end{abstract}

Keywords: customer relationship management, customer relationship model, customer relationship component, hospitals

\section{Introduction:}

A strong relationship with customers is the key to success in business. Root concept of "customer relationship management" is the old axiom that "the customer is always right." In recent years, academics, software vendors and consultants have been involved in this field of business and developed the concept of customer relationship management, which means the efforts of organizations to create and deliver higher value to the customer. [1]

Organizations recognize that their customers are the most important asset and known the relation with them as an exchange and mutual benefit and opportunities that require management. [2]

Customer relationship management is a business strategy that pays on recruitment, retention and improved of customer. With proper implementation of customer relationship management, Organizations will be able to mentioned three tasks by paying a lower cost. This in an era of globalization and when an organization may have millions of customer would not be possible 
without the use of Information and Communication Technology. IT is a tool to implement CRM by which organizations can communicate with individual customers in such a way that the client is the only client Nations. Today, only the organizations are successful and can continue their activities that can attract and retain more loyal customers.

\section{Literature and background study:}

Paying attention to the expected customer value, leading to satisfaction and loyalty and frequent visits to the organization, will be provided. In the field of health care although a patient may be treated but there is no guarantee that person is not sick again. Furthermore, some cases require continuous treatment and rehabilitation. For example, in some diseases such as hypertension and diabetes, with one therapy, health can not be achieved but it does require ongoing care and treatment. The CRM in the healthcare industry is a tool to gain customer loyalty and lifetime value provided for him. Now we have said it that what are the factors which influenced in customer satisfaction in the field of health care and which plan can meet the expectations of customers In order to implement customer relationship management.

With numerous reviews and detailed case studies Since 1992 to present and With more than 40 models offered in the field of customer relationship management that have come in table 1 We have attempted to provide a new pattern In the field of customer relationship management in health centers.

Table 1: Model presented in the field of customer relationship management

\begin{tabular}{|c|c|c|c|c|c|c|c|c|}
\hline source & Researcher & Year & source & Researcher & year & Source & researcher & year \\
\hline$[31]$ & Roh & 2005 & {$[17]$} & Fornell & 1994 & {$[3]$} & Forensell & 1992 \\
\hline$[32]$ & Liu & 2006 & {$[18]$} & Estas & 1997 & {$[4]$} & Fornell & 1996 \\
\hline$[33]$ & Kassim & 2010 & {$[19]$} & Soderland & 1998 & {$[5]$} & Bruhn & 1998 \\
\hline$[34]$ & Chang & 2009 & {$[20]$} & Hackle & 2000 & {$[6]$} & Eklof & 2000 \\
\hline$[35]$ & Kwan & 2009 & {$[21]$} & Juhance & 2001 & {$[7]$} & Chan & 2003 \\
\hline$[36]$ & Yap & 2012 & {$[22]$} & Andressen & 1998 & {$[8]$} & Vilares & 2003 \\
\hline$[37]$ & Jiao & 2012 & {$[23]$} & Dimitriades & 2006 & {$[9]$} & Hellier & 2003 \\
\hline$[38]$ & Mohsen & 2011 & {$[24]$} & Li & 2006 & {$[10]$} & Wang & 2004 \\
\hline$[39]$ & Kumar & 2011 & {$[25]$} & Hsu & 2006 & {$[11]$} & Brelly & 2004 \\
\hline$[40]$ & Hoq & 2010 & {$[26]$} & Turkyilmaz & 2007 & {$[12]$} & Gue & 2004 \\
\hline$[41]$ & Moreno & 2014 & {$[27]$} & Hafiz & 2010 & {$[13]$} & Heydarzade & 2005 \\
\hline$[42]$ & Sebjan & 2014 & {$[28]$} & Hsu & 2008 & {$[14]$} & Ball & 2004 \\
\hline$[43]$ & Harical & 2015 & {$[29]$} & Bai & 2011 & {$[15]$} & Aydin & 2005 \\
\hline$[44]$ & Santoso & 2015 & {$[30]$} & Kim & 2012 & {$[16]$} & Redondo & 2005 \\
\hline & & & & & & {$[45]$} & Martin & 2016 \\
\hline
\end{tabular}




\subsection{Research model:}

After evaluating the previous models, we have attempted to present, a new model that have come in figure 1.

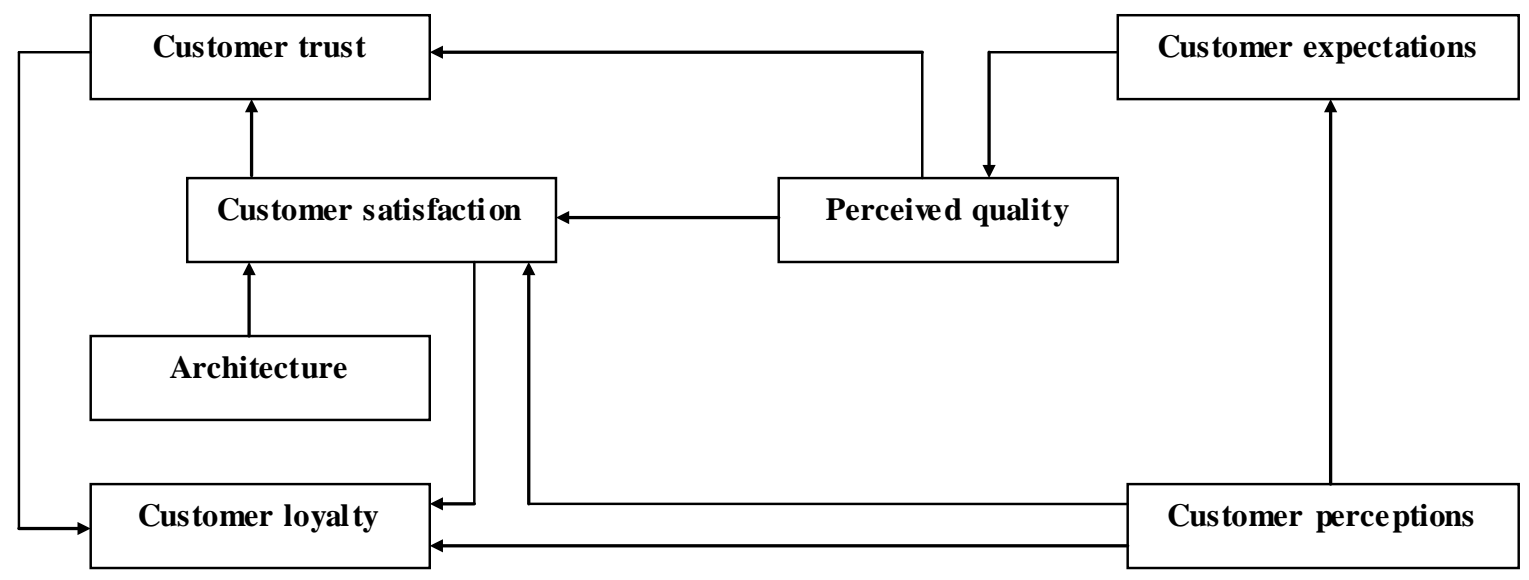

Figure 1: Research proposal model

\subsection{Sampling survey:}

Like many ways readiness assessment, a questionnaire was used In this study . On the first page we appreciate the people and explained a brief description of the customer relationship management process with its indicators for the interviewee. in the following we asked 30 questions about CRM implementation that number of three questions related to demographic and 27 questions are about the main variables. the questions are in Likert spectrum and Includes five options as very high, high, medium, low and very low that Rank them in order of 1,2,3,4,5 . The number of returned questionnaires are 324 that because of impaired completion of some questionnaires, 21 questionnaires were eliminated and Total questionnaires that were involved in the analysis was 303 number.

\section{3. hypothesis:}

First hypothesis: customer perceptions affect on customer expectations.

The second hypothesis: customer's perceptions affect on customer satisfaction.

The third hypothesis: customer perceptions affect on customer loyalty.

The fourth hypothesis: customer expectations affect on quality influences.

Fifth hypothesis: perceived quality affect on trust.

Sixth hypothesis: perceived quality affect on customer satisfaction.

The seventh hypothesis: Trust affect on customer loyalty. 
Eighth hypothesis: the architectural affect on customer satisfaction.

Ninth hypothesis: customer satisfaction affect on trust.

Tenth hypothesis: customer satisfaction affect on loyalty.

\section{Results:}

By examining the assumptions and Computing Pearson correlation coefficient of Components, the results shows in Table 2 .

Table 2: The results of the data analysis

\begin{tabular}{|c|c|c|c|c|c|c|}
\hline $\begin{array}{c}\text { Type of } \\
\text { Relationship }\end{array}$ & Relationship & Number & Significant & $\begin{array}{l}\text { Pearson } \\
\text { coefficient }\end{array}$ & $\begin{array}{c}\text { dependent } \\
\text { variable }\end{array}$ & $\begin{array}{l}\text { independent } \\
\text { variable }\end{array}$ \\
\hline Direct & Yes & 303 & 0.002 & 0.304 & $\begin{array}{c}\text { Customer } \\
\text { expectations }\end{array}$ & $\begin{array}{c}\text { Customer } \\
\text { perceptions }\end{array}$ \\
\hline Direct & Yes & 303 & 0.004 & 0.282 & $\begin{array}{c}\text { Customer } \\
\text { satisfaction }\end{array}$ & $\begin{array}{l}\text { Customer } \\
\text { perceptions }\end{array}$ \\
\hline Direct & Yes & 303 & 0.001 & 0.326 & $\begin{array}{c}\text { Customer } \\
\text { loyalty }\end{array}$ & $\begin{array}{l}\text { Customer } \\
\text { perceptions }\end{array}$ \\
\hline Direct & Yes & 303 & 0.005 & 0.276 & $\begin{array}{c}\text { Perceived } \\
\text { quality }\end{array}$ & $\begin{array}{c}\text { Customer } \\
\text { expectations }\end{array}$ \\
\hline Direct & Yes & 303 & 0.014 & 0.244 & Customer trust & $\begin{array}{c}\text { Perceived } \\
\text { quality }\end{array}$ \\
\hline Direct & Yes & 303 & 0.001 & 0.318 & $\begin{array}{c}\text { Customer } \\
\text { satisfaction }\end{array}$ & $\begin{array}{c}\text { Perceived } \\
\text { quality }\end{array}$ \\
\hline Direct & Yes & 303 & 0.027 & 0.221 & $\begin{array}{c}\text { Customer } \\
\text { loyalty }\end{array}$ & Customer trust \\
\hline Direct & Yes & 303 & 0.023 & 0.181 & $\begin{array}{c}\text { Customer } \\
\text { satisfaction }\end{array}$ & Architecture \\
\hline Direct & Yes & 303 & 0.000 & 0.587 & Customer trust & $\begin{array}{c}\text { Customer } \\
\text { satisfaction }\end{array}$ \\
\hline Direct & Yes & 303 & 0.000 & 0.491 & $\begin{array}{c}\text { Customer } \\
\text { loyalty }\end{array}$ & $\begin{array}{c}\text { Customer } \\
\text { satisfaction }\end{array}$ \\
\hline
\end{tabular}

The results can show the proposed new model is true.

\section{Conclusion:}

\section{Customer perceptions affect on customer expectations:}

As it was shown, with 0.304 Pearson correlations and having 95\% Confidence level, there is a direct, positive and significant relationship between customer expectations and perceptions of customers. In other words, with the increase in the perceptions of customers, we have increased in customer expectations. 


\section{Customer perceptions affect on customer satisfaction:}

As it was shown, with 0.282 Pearson correlations and having 95\% Confidence level, there is a direct, positive and significant relationship between customer satisfaction and perceptions of customers. In other words, with the increase in the perceptions of customers, we have increased in customer satisfaction.

\section{Customer perceptions affect on customer loyalty:}

As it was shown, with 0.326 Pearson correlations and having 95\% Confidence level, there is a direct, positive and significant relationship between customer loyalty and perceptions of customers. In other words, with the increase in the perceptions of customers, we have increased in customer loyalty.

\section{Customer expectations affect on quality influences:}

As it was shown, with 0.276 Pearson correlations and having 95\% Confidence level, there is a direct, positive and significant relationship between quality influences and expectations of customers. In other words, with the increase in the expectations of customers, we have increased in quality influences.

\section{Perceived quality affect on trust:}

As it was shown, with 0.244 Pearson correlations and having 95\% Confidence level, there is a direct, positive and significant relationship between trust and Perceived quality. In other words, with the increase in the Perceived quality, we have increased in trust.

\section{Perceived quality affect on customer satisfaction:}

As it was shown, with 0.318 Pearson correlations and having 95\% Confidence level, there is a direct, positive and significant relationship between customer satisfaction and Perceived quality. In other words, with the increase in the Perceived quality, we have increased in customer satisfaction.

\section{Trust affect on customer loyalty:}

As it was shown, with 0.221 Pearson correlations and having 95\% Confidence level, there is a direct, positive and significant relationship between customer loyalty and Trust. In other words, with the increase in the Trust, we have increased in customer loyalty.

\section{The architectural affect on customer satisfaction:}

As it was shown, with 0.181 Pearson correlations and having 95\% Confidence level, there is a direct, positive and significant relationship between customer satisfaction and architectural. In other words, with the increase in the architectural, we have increased in customer satisfaction. 


\section{Customer satisfaction affect on trust:}

As it was shown, with 0.587 Pearson correlations and having 95\% Confidence level, there is a direct, positive and significant relationship between trust and Customer satisfaction. In other words, with the increase in the Customer satisfaction, we have increased in trust.

\section{Customer satisfaction affect on loyalty:}

As it was shown, with 0.491 Pearson correlations and having 95\% Confidence level, there is a direct, positive and significant relationship between loyalty and Customer satisfaction. In other words, with the increase in the Customer satisfaction, we have increased in loyalty.

\section{References:}

1. Melin Stone, Bryan Foss ؛” CRM in financial services” 2002 .

2. Plakoyiannaki, e ؛(2005) "how do organizational members perceived CRM? Evidence from a U.K. service firm” journal of marketing management, 21, 363-392.

3. Fornell, C., A national customer satisfaction barnomer: the Swedish experience the Journal of Marketing, 1992:p. 6-21.

4. Fornell, C., et al., The American customer satisfaction index : nature, purpose, and findings. The Journal of Marketing. 1996: p. 7-18.

5. Bruhn, M. and M.A. Grund, Theory, development and implementation of national customer satisfaction indices: the Swiss Index of Customer Satisfaction (SWICS).Total Quality Management . 2000. 11(7) : p. 1017-1028.

6. Eklof, J.A , European customer satisfaction index pan-European telecommunication sector report based on the pilot studies 1999. European Organization for Quality and European for Quality Management, Stockholm, Sweden,2000.

7. Chan, L.K., et al., Consumer satisfaction index : new practice and findings European Journal of Marketing. 2003.37(5/6): p. 872-909.

8. Vilares, M.J and P.S Coelho, The employee-customer satisfaction chain in the ECSI model. European Journal of Marketing , 2003.37(11/12): p. 1703-1722.

9. Hellier, P.K., et al., Customer repurchase intention : a general structural equation model. European journal of marketing. 2003,37(11/12):p. 1762-1800.

10. Wang. Y., et al., An integrated framework for customer value and customer-relationshipmanagement performance: acustomer-based perspective from China Managing market. European Journal of Marketing, 2004. 14(2/3): p. 169-182 
12. Guo, C., A. Kumar, and P. Jiraporn, Customer satisfaction and profitability: in there a lagged effect? Journal of Strategic Marketing. 2004. 12(3): 129-144.

14. Ball, D., P.S. Coelho, and A. Machas, The role of communication and trust in explaining customer loyalty: an extension to the ECSI model. European Journal of Marketing. 2004. 38(9/10):p. 1271-1293.

15. Aydin, S. and G. Ozer, National customer satisfaction indices: animplementation in the Turkish mobile telephone market. Marketing Intelligence and Planning, 2005. 23(5): p. 486504

16. Redondo, Y.P. and H.J.C Fierro, Moderationg effect of type of product exchanged in longterm orientation of firm-supplier relationships: an empirical study. Journal of Product and Brand Management, 2005. 14(7):p. 424-437.

17. Fornell, C., et al., The American customer satisfaction index : nature, purpose, and findings. The Journal of Marketing. 1996: p. 7-18.

19. Soderlund. M.,Customer satisfaction and its consequences on customer behaviors revisited: The impact of different levels of satisfaction on work-of-mouth, feedback to the supplier and loyalty. International Journal of Service Industry Management 1998. 9(2) : p. 169-188.

20. Hackl, P., D. Scharizer, and R.Zuba. Customer satisfaction in the Austrain food retail market. Total Quality Management , 2000. 11(7):p. 999-1006.

22. Andressen , T.W. and B. Lindestad, Customer loyalty and complex services the impact of corporate image on quality, customer satisfaction and loyalty for customer with varying degrees of service expertise. International Journal of service Industry Management, 1998. 9 (1):p. 7-23.

23. Dimitriades, Z.S., Customer satisfaction , loyalty and commitment in service organizations: some evidence from Greece. Management Research News, 2006. 29(12):p. 782-800.

24. Li, B., et al., A comparison study of customer satisfaction between the UPS and FedEx: an empirical study among university customers. Industrial Management and Data Systems, 2006. 106(2): p. 182-199.

25. Hsu, S.-H Chen, and J.-T. Hsueh, Application of customer satisfaction study to derive customer Knowledge. Total Quality Management and Business Excellence , 2006. 17(04):p. 439-454.

26. Turkyilmaz, A. and C. Qzkan, Development of a customer satisfaction index model: An application to the Turkish mobile phon sector. Industrial Management and Data Systems, 2007. 107(5) :p.627-687. 
28. Hsu. S.-H., Developing an index for online customer satisfaction: Adaptation of American customer Satisfaction Index. Expect Systems with Applications, 2008.34(4):p. 3033-304

29. He, J. and Y . Bai, Assessing the relationship among service quality. Customer satisfaction and behavioral intentions in online shopping environments.in Business Intelligence and Financial Engineering (BIFE), 2011 Fourth International Conference on, 2011. IEEE.

30. Kim , C., et al., Factors influencing Internet shopping value and customer repurchase intention. Electronic Commerce Research and Applications, 2012. 11(4):p. 374-387.

31. Roh, T.H., c.k. Ahn, and I. Han, The priority factor model for customer relationship management system success, Expert systems with application , 2005.28(4): p. 641-654.

32. Liu, Y., C.-F. Zhou, and Y.-W. Chen, Determinants of E-CRM in influencing customer satisfaction , in PRICAI 2006: Trends in Artificial Intelligence. 2006,Springer. P. 767-776.

33. Kassim, N. and N.A. Abdullah, The effect of perceived service quality dimensions on customer satisfaction , trust,and Ioyalty in e-commerce settings: a cross cultural analysis. Asia Pacific Journal of Marketing and Logistics,2010.22(3): p. 351-371.

34. Chang, H.H. and S.W. Chen, Consumer perception of interface quality, security.and loyalty in electronic commerce. Information and Management, 2009. 46(7): p. 411-417.

36. Yap, B.W ., T. Ramayah, and W.N.W. shahidan , satisfaction and trust on customer Ioyalty: a PLS approach, Business strategy series, 2012. 13(4) :p. 154-167 .

37. Jiao, Y., Yang, and Z.Zhu. An Empirical study of Customer Loyalty to internet Banking in China. In e.Business Engineering (ICEBE), 2012 IEEE Ninth International Conference on.2012.IEEE.

38. Mohsin, Z., Z., Arshad . and u.R. Kashif, impact of online service quality on customer satisfaction in banking sector of Pakistan. African Journal of Business Management , 2011.5(30):p. 11786-11793.

40. Hoq. M.Z.,N. Suatana, and M.Amin , the effect of trust , customer satisfaction and Image on Customers' Loyalty in Islamic Banking Sector . South Asian journal of management, 2010.17(1).

41.Aurora Garido-Morendo؛ Nigel locket ؛ Victor Garcia Morales "the mediating roll of knowledge management and organizational commitment” journal of information and management 51(2014) 1031-1042.

42.Sebjan, Urban ؛ Bobek, Samo ؛ Tominc, Polona “organizational factors influencing effective use of CRM solutions” Procedia technology 16 (2014) 459-470. 
43.Harrigan , Paul ؛ Soutar ,Geoff ؛ Musfic Mannan Choudhury ؛ Lowe, Michelle "modeling CRM in a social age” Australian marketing journal 23 (2015) 27-33.

44.Santoso , Adhi Setyo ؛ Erdaka, Arlo "customer loyalty in collaborative consumption model : empirical study of CRM for product-service system-based e-commerce in Indonesia" Procedia computer science 72(2015) 543-551.

45.Martin, San ؛ Jimenez, N.H. , Catalan , B.L "the firms benefits of mobile CRM from the relationship marketing approach and the TOE model” Spanish journal of marketing- ESIC 20 (2016) 18-29. 